\title{
Pemberdayaan Karang Taruna dalam Pencegahan Penyebaran Covid-19 di Desa Wonokerto Kecamatan Wonogiri
}

\author{
Sugiyarto $^{1^{*}}$ \\ ${ }^{1}$ Jurusan Keperawatan, Poltekkes Kemenkes Surakarta \\ *Email: sugiy1077@gmail.com
}

\begin{abstract}
Background: Corona Virus Disease-19 (COVID-19) is an infectious disease caused by the SARS-COV 2 virus or Corona Virus. COVID-19 is declared as a world pandemic by WHO and is determined by the Government as a non-natural disaster in the form of disease outbreaks that needs to be taken integrated countermeasures including the involvement of all components of the community. The purpose of community service activities in the form of empowering youth groups in preventing the spread of covid-19 in Timang Kulon Village Wonokerto Wonogiri Village is expected to increase the understanding and knowledge of cadets related to preventing the spread of covid-19 so as to contribute to preventing the spread of covid-19 in Timang Kulon, Wonokerto, Wonogiri. Methods: Health education and Pasting the Covid-19 prevention posters in public places and distributing masks to the public. Results: The results of the post-test assessment showed that there was an increase in the knowledge of youth groups from $73 \%$ to 95\% after health counseling. Conclusion: The knowledge of youth organization has increased and this activity requires follow-up, i.e. monitoring community behavior related to preventing the spread of Covid-19.
\end{abstract}

Keywords: health counseling, prevention of covid-19 spread, youth organization

\section{PENDAHULUAN}

Corona Virus Disease-19 (COVID-19) adalah penyakit yang menular disebabkan oleh virus SARS-COV 2 atau Virus Corona. COVID-19 dinyatakan sebagai pandemi di dunia oleh WHO dan ditetapkan oleh Pemerintah sebagai bencana non alam dalam bentuk wabah penyakit yang perlu diambil dalam tindakan respons terpadu termasuk keterlibatan semua komponen masyarakat. Kasus yang pertama pasien dengan hasil konfirmasi positif Covid-19 di Indonesia diumumkan oleh Presiden pada tanggal 2 Maret 2020 sejumlah 2 pasien. Kasus konfirmasi positif setiap hari terus meningkat pada tanggal tanggal 19 April 2020, dilaporkan total kasus konfirmasi Covid-19 positif adalah 6.575 dengan kematian 582 (CFR 8,85\%) dan dengan pasien sembuh $686(10,43 \%)$. Daerah yang mengalami kenaikan paling tinggi yaitu di DKI Jakarta yaitu sebanyak 131 kasus (Kemkes.go,id, 2020). Sedangkan untuk di Kabupaten Wonogiri sampai tanggal 18 April 2020 telah dilaporkan jumlah total kasus pasien dengan Covid-19 positif adalah 2 kasus, 1 pasien sembuh, 1 pasien meninggal, dan tidak ada pasien yang dirawat dengan Covid-19 positif, sedangkan total Orang Dalam Pemantauan (ODP) sejumlah 405 orang, dengan rincian pemantauan saat ini 203 orang, selesai pemantauan 202 orang. Untuk total Pasien Dalam Pengawasan (PDP) sejumlah 37 orang, yaitu 3 orang sedang dirawat, 33 orang sembuh, 1 orang meninggal dengan hasil swab negatif (Pemkab Wonogiri, 2020).

Data terbaru sampai dengan tanggal 31 Mei 2020 kasus konfirmasi positif Covid-19 di Indonesia maupun di Dunia terus mengalami peningkatan. Di Indonesia penambahan kasus konfirmasi positif per tanggal 31 Mei 2020 sejumlah 700 kasus 
sehingga total kasus pasien dengan konfirmasi positif Covid-19 menjadi 26.473 kasus dengan total kematian 1.613 (CFR 6,1 \%) dan total pasien sembuh 7.308 $(27,6 \%)$ dan pasien positif masih dalam pengawasan sejumlah 17.552 pasien (Kemkes.go.id). Dari data di atas menunjukkan bahwa Covid-19 masih mengalami peningkatan secara signifikan sehingga perlu adanya kerjasama seluruh lapisan masyarakat dalam membantu pemerintah dalam rangka memutus rantai penyebaran Covid-19 yaitu dengan melibatkan partisipasi semua komponen masyarakat.

Pemberdayaan masyarakat dalam pencegahan Covid-19 adalah semua upaya yang dilakukan oleh semua komponen masyarakat dengan potensi yang dibutuhkan oleh komunitas yang diberdayakan dan mampu mendukung dan mencegah transmisi Covid-19 (Kemenkes RI, 2020). Komponen masyarakat salah satunya adalah organisasi kepemudaan atau karang taruna, yang merupakan pengembangan organisasi sosial pemuda yang tumbuh dan berkembang berdasar kesadaran dan tanggung jawab sosial dari, oleh dan untuk masyarakat atas dasar pemuda di suatu wilayah desa. Karang Taruna memiliki peran yang penting untuk ikut andil dalam pencegahan penyebaran Covid-19 khususnya di dusun Timang Kulon Desa Wonokerto Kabupaten Wonogiri karena pemuda adalah generasi penerus bangsa yang memiliki semangat jiwa muda, inovasi, dan kreativitas.

Desa Wonokerto merupakan salah satu Desa di Kabupaten Wonogiri. Daerah tersebut berbatasan langsung dengan Kecamatan Nguter Kabupaten Sukoharjo dan Kecamatan Jatipuro Kabupaten Karanganyar. Sejak tahun 2017 di Desa Wonokerto berdiri sebuah pabrik kertas, yang mana pabrik tersebut memiliki karyawan dari berbagai daerah. Sehingga hal tersebut perlu di waspadai sebagai penyebab penyebaran virus corona, selain itu beberapa warga Desa Wonokerto adalah seorang perantauan yang mencari nafkah di kota besar seperti Jakarta, Surabaya dan Bogor. Sudah kita ketahui bersama bahwa daerah- daerah tersebut memiliki angka kejadian Covid 19 yang cukup timggi. Dan dikhawatirkan para perantauan mudik ke kampung halaman. Hal ini bisa sebagai rantai penyebaran virus corona di Desa Wonokerto khususnya di Dusun Timang Kulon. Sehingga perlu adanya sosialiasi kepada masyarakat terkait pencegahan penyebaran Covid-19.

Tujuan kegiatan pengabdian kepada masyarakat berupa pemberdayaan karang taruna dalam pencegahan penyebaran Covid-19 di Dusun Timang Kulon Desa Wonokerto Wonogiri. Diharapkan dapat meningkatkan pemahaman dan pengetahuan karang taruna terkait pencegahan penyebaran Covid-19 sehingga dapat berkontribusi mencegah penyebaran covid-19 di Dusun Timang Kulon Wonokerto Wonogiri.

\section{TINJAUAN PUSTAKA}

\subsection{Pendidikan Kesehatan dan Pemberdayaan Masyarakat}

Pendidikan kesehatan dalam arti pendidikan secara umum adalah semua upaya yang direncanakan dalam rangka mempengaruhi orang lain, individu, kelompok, atau komunitas/ masyarakat, sehingga mereka melakukan hal yang diharapkan oleh seseorang yang memberikan pendidikan atau promosi kesehatan (Notoatmodjo, 2012). Metode yang digunakan dalam kegiatan pengabdian masyarakat adalah dengan metode ceramah melalui media online Zoom Meeting. 
Pemberdayaan masyarakat dalam pencegahan Covid-19 adalah semua upaya yang dilakukan oleh semua komponen masyarakat dengan potensi yang dibutuhkan oleh komunitas yang diberdayakan dan mampu mendukung dan mencegah transmisi Covid-19 (Kemenkes RI, 2020). Pemberdayaan masyarakat yang dilakukan adalah dengan memberikan informasi atau pengetahuan tentang pencegahan Covid-19, Pemasangan poster pencegahan Covid-19 di tempat umum, dan melakukan pembagian masker kepada masyarakat.

\subsection{Covid-19}

Covid-19 adalah suatu penyakit yang disebabkan oleh turunan corona virus baru. Istilah 'CO' diambil dari corona, 'VI' adalah virus, dan ' $\mathrm{D}$ ' adalah disease (penyakit). Sebelumnya, penyakit ini disebut dengan '2019 novel corona virus' atau '2019- nCoV.' Virus Covid-19 adalah virus baru terkait dengan keluarga virus yang sama dengan Severe Acute Respiratory Syndrome (SARS) dan beberapa jenis dari virus flu biasa.

Tanda dan gejala umum seseorang terinfeksi Covid-19 yaitu mengalami gejala gangguan pernapasan akut seperti demam, sesak napas, dan batuk. Masa inkubasi rata-rata dari virus ini adalah 5-6 hari dengan masa inkubasi paling lama 14 hari. Pada pasien yang sudah mengalami keparahan, Covid-19 bisa menyebabkan pasien mengalami pneumonia, gagal ginjal, sindrom pernapasan akut, dan bahkan menyebabkan kematian. Tanda dan gejala klinis yang dilaporkan pada sebagian besar kasus adalah kondisi demam, dengan beberapa kasus mengalami kesulitan dalam bernapas, dan pemeriksaan rontgen thorax menunjukkan hasil tampak infiltrat pneumonia yang luas di kedua lapang paru (Kemenkes RI, 2020).

Virus Covid-19 bisa ditularkan melalui kontak langsung lewat percikan dari saluran napas seseorang yang sudah terinfeksi virus Covid-19 (yang keluar melalui batuk atau bersin). Seseorang dapat terinfeksi karena menyentuh permukaan yang sudah terkontaminasi virus ini lalu menyentuh wajahnya (seperti mata, mulut, dan hidung). Virus Covid-19 dapat bertahan di atas permukaan benda yang sudah terpapar selama beberapa jam akan tetapi dapat dibunuh dengan disinfektan (WHO, 2020).

Seperti halnya infeksi saluran nafas lain seperti flu atau batuk pilek, tindakan dalam menjaga kesehatan bersama sangatlah penting dalam rangka memperlambat penyebaran Covid-19. Tindakan yang dilakukan dalam menjaga kesehatan bersama adalah tidak keluar rumah saat merasa sakit, menutup mulut dan hidung dengan tisu atau siku terlipat saat batuk atau bersin dan segera buang tisu yang telah digunakan tersebut, rajin dalam mencuci tangan dengan sabun dan air yang mengalir, membersihkan permukaan, benda atau alat yang sering disentuh, hindari menyentuh wajah terutama hidung, mata, dan mulut, gunakan masker saat meninggalkan rumah, jaga jarak 1 meter dari orang lain, hindari kerumunan, hindari tempat- tempat yang ramai, dan ikuti anjuran dari pemerintah (WHO, 2020). 


\section{METODE}

Pengabdian kepada masyarakat dilaksanakan pada Bulan April Tahun 2020. Pesertanya adalah anggota Karang Taruna Timang Kulon Wonokerto dengan jumlah peserta sebanyak 45 orang.

Metode yang diterapkan dalam program kegiatan pengabdian kepada masyarakat adalah sebagai berikut:

a. Penyuluhan kesehatan; Untuk meningkatkan pengetahuan tentang pencegahan penyebaran Covid-19, peserta diberikan edukasi melalui metode penyuluhan Kesehatan dengan memberikan penjelasan tentang Covid-19 meliputi pengertian, tanda dan gejala, penyebab, cara penyebaran Covid-19, cara pencegahan penyebaran Covid-19, cara mencuci tangan, etika batuk, dan cara dalam menggunakan masker. Peserta dijelaskan tentang materi tersebut di atas melalui system daring yaitu media zoom dan grup Whatsapp. Materi yang diberikan dishare di grup Whatsapp kemudian dibahas lebih lengkap melalui meeting zoom.

b. Melakukan penempelan poster- poster pencegahan Covid-19 di tempat- tempat umum dan melakukan pembagian masker kepada masyarakat.

\section{HASIL}

Hasil pre-test kegiatan penyuluhan kesehatan untuk karang taruna menunjukkan bahwa sebagian besar karang taruna (78\%) mengetahui mengenai pencegahan penyebaran covid-19. Materi penyuluhan meliputi pengertian, tanda dan gejala, penyebab, cara penyebaran Covid-19, cara dalam mencegah penyebaran Covid-19, etika batuk, cara mencuci tangan dan cara dalam menggunakan masker. Peserta yang mengikuti meeting zoom sangat antusias dan aktif bertanya tentang materi Covid-19. Hasil post-test menunjukkan bahwa terdapat peningkatan pengetahuan karang taruna dari $73 \%$ menjadi $95 \%$ setelah dilakukan penyuluhan kesehatan.

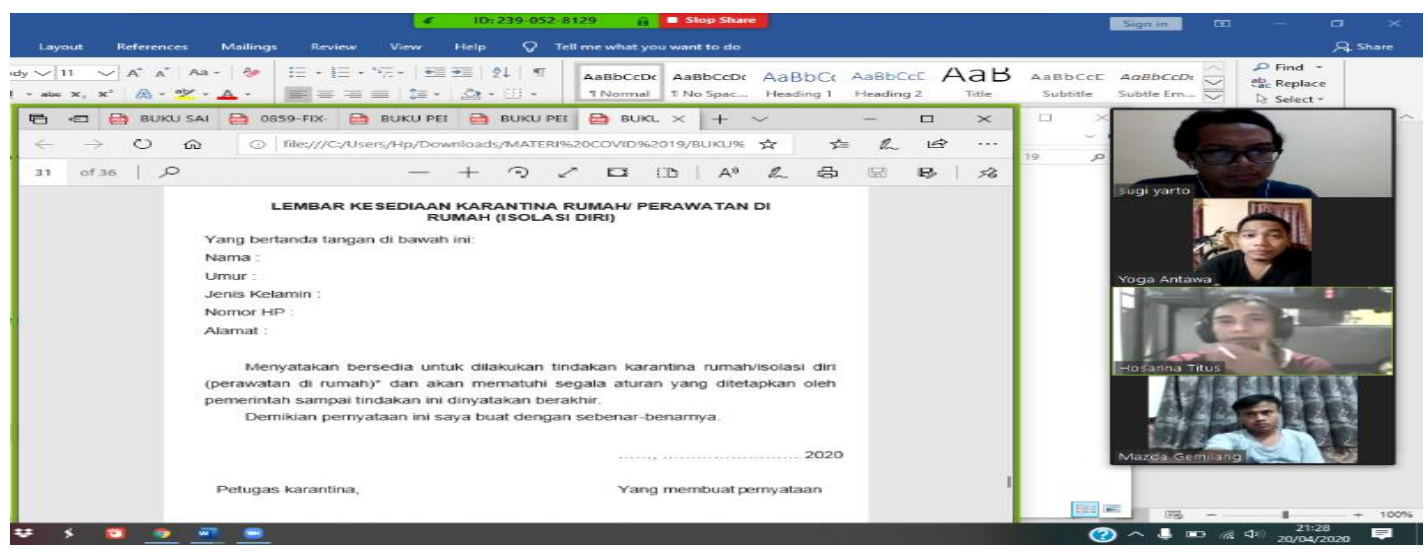

Gambar 1. Penyuluhan Kesehatan melalui Media Online Zoom Meeting

Hasil Evaluasi Pengabdian kepada masyarakat menunjukkan bahwa karang taruna sangat aktif dan antusias dalam mengikuti setiap kegiatan,yaitu aktif dalam mengikuti kegiatan penyuluhan Kesehatan melalui online, melakukan pemasangan 
poster-poster pencegahan penyebaran covid-19 di tempat- tempat umum, melakukan pembagian masker dan sosialisasi kepada masyakarat. Sehingga saat ini masyarakat sudah melakukan tindakan-tindakan pencegahan penyebaran covid-19 yaitu dengan selalu rajin mencuci tangan, menghindari kerumunan, melakukan etika batuk yang benar, dan menggunakan masker saat keluar rumah. Data terkahir yang didapat, di Desa Wonokerto sampai saat ini belum ada kasus konfirmasi positif Covid-19 hal ini menunjukkan bahwa masyarakat di Desa Wonokerto sangat proaktif dalam pencegahan penyebaran Covid-19.

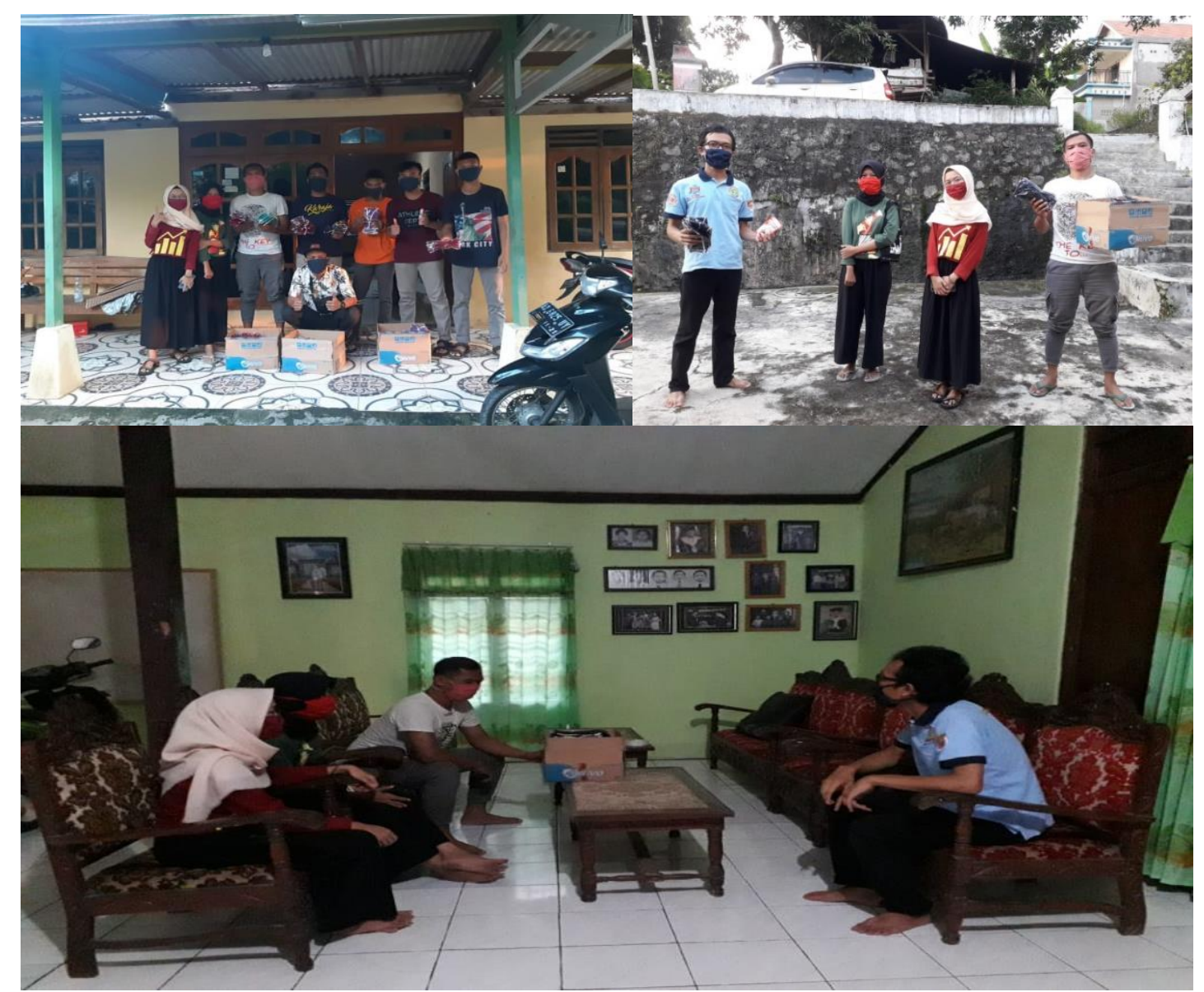

Gambar 2. Pembagian Masker Kepada Masyarakat

\section{PEMBAHASAN}

Kegiatan Pengabdian Masyarakat dilakukan dengan memberikan Pendidikan Kesehatan atau penyuluhan kepada karang taruna terkait pencegahan penyebaran covid-19. Pendidikan kesehatan dalam arti pendidikan secara umum adalah semua upaya yang direncanakan dalam rangka mempengaruhi orang lain, individu, kelompok, atau komunitas/ masyarakat, sehingga mereka melakukan hal yang diharapkan oleh seseorang yang memberikan pendidikan atau promosi kesehatan (Notoatmodjo, 2012). Pendidikan Kesehatan dilakukan dengan metode ceramah melalui media online zoom meeting dan pemberian materi dan pamflet melalui Grup 
Whatsapp. Dari hasil Pengabdian masyarakat yang dilakukan didapatkan bahwa pengetahuan karang taruna tentang pencegahan penyebaran Covid-19 mengalami peningkatan. Pengetahuan pada karang taruna mengalami peningkatan setelah diberikan penyuluhan kesehatan tentang pencegahan penyebaran Covid-19 melalui media online yaitu zoom meeting dan Grup Whatsapp. Pengetahuan yang meningkat akan mempengaruhi terjadinya perubahan perilaku masyarakat, sesuai dengan teori (Notoatmodjo, 2012) bahwa perubahan perilaku dipengaruhi faktor predisposisi. Faktor predisposisi adalah faktor internal yang ada pada diri seseorang, kelompok, dan masyarakat yang mempengaruhi seseorang dalam berperilaku seperti pengetahuan, sikap, kepercayaan, nilai-nilai dan juga budaya.

Tindakan pencegahan Covid-19 yang bisa dilakukan oleh masyarakat yaitu dengan menjaga Ventilasi di rumah agar sianar matahari bisa masuk dan bisa menghancurkan virus. Pengunaan masker sederhana dan penerapan etika batuk yang benar, dan sering mencuci tangan (Singhal, 2020). Poin utama dalam mencegah penyebaran Covid-19 di masyarakat adalah dengan selalu menjaga kebersihan tangan, jarak sosial dan karantina. Dengan peningkatan kapasitas pengujian laboratorium, hal ini dapat mendeteksi lebih banyak kasus pasien positif Covid-19 di masyarakat (Güner et al., 2020).

Seperti halnya infeksi saluran nafas lain seperti flu atau batuk pilek, tindakan dalam menjaga kesehatan bersama sangatlah penting dalam rangka memperlambat penyebaran Covid-19. Tindakan yang dilakukan dalam menjaga kesehatan bersama adalah tidak keluar rumah saat merasa sakit, menutup mulut dan hidung dengan tisu atau siku terlipat saat batuk atau bersin dan segera buang tisu yang telah digunakan tersebut, rajin dalam mencuci tangan dengan sabun dan air yang mengalir, membersihkan permukaan, benda atau alat yang sering disentuh, hindari menyentuh wajah terutama hidung, mata, dan mulut, gunakan masker saat meninggalkan rumah, jaga jarak 1 meter dari orang lain, hindari kerumunan, hindari tempat-tempat yang ramai, dan ikuti anjuran dari pemerintah (WHO, 2020).

\section{KESIMPULAN DAN SARAN}

\subsection{Kesimpulan}

Berdasarkan hasil kegiatan pengabdian masyarakat dapat disimpulkan bahwa pengetahuan karang taruna terkait pencegahan penyebaran Covid-19 mengalami peningkatan, yaitu dari $73 \%$ menjadi $95 \%$. Karang taruna sangat aktif dan antusias dalam mengikuti setiap kegiatan, Yaitu aktif dalam mengikuti kegiatan penyuluhan Kesehatan melalui online, melakukan pemasangan poster pencegahan penyebaran covid-19 di tempat-tempat umum, melakukan pembagian masker dan sosialisasi kepada masyakarat.

\subsection{Saran}

Dalam kegiatan Pengabdian masyarakat ini diperlukan tindak lanjut yaitu dengan melakukan monitoring perilaku masyarakat dalam pencegahan penyebaran Covid-19. 


\section{UCAPAN TERIMA KASIH}

Dengan terlaksananya kegiatan pengabmas ini dengan baik kami haturkan banyak terimakasih kepada Satino, SKM., MSc. selaku Direktur Politeknik Kesehatan Kemenkes Surakarta, Widodo, MN. Selaku Ketua Jurusan Keperawatan Politeknik Kesehatan Kemenkes Surakarta dan Yuyun Setyorini,SKp,Ns.,MKep, selaku Kepala Unit Pengabdian Masyarakat Politeknik Kesehatan Kemenkes Surakarta yang telah mendukung kegiatan pengabdian kepada masyarakat ini sehingga kegiatan ini dapat dilaksanakan dengan baik.

\section{DAFTAR RUJUKAN}

Güner, R., Hasanoğlu, İ., \& Aktaş, F. (2020). Covid-19: Prevention and control measures in community. Turkish Journal of Medical Sciences, 50(SI-1), 571577. https://doi.org/10.3906/sag-2004-146

Kemenkes RI. (2020a). Pedoman Pemberdayaan Masyarakat dalam Pencegahan Covid-19 di RT/ RW/ Desa.Jakarta.

Kemenkes RI. (2020b). Pedoman Pencegahan dan Pengendalian Coronavirus Disease (COVID-19). Germas, 0-115.

Notoatmodjo, S. (2012). Promosi Kesehatan \& Ilmu Perilaku. In Jakarta: Rineka Cipta.

Singhal, T. (2020). A Review of Coronavirus Disease-2019 (COVID-19). Indian Journal of Pediatrics, 87(4), 281-286. https://doi.org/10.1007/s12098-02003263-6

WHO. (2020). Pesan dan Kegiatan Utama Pencegahan dan Pengendalian COVID-19 di Sekolah.Unicef, 1, 1-14. lbender@unicef.org

Wonogirikab.go.id (2020, 18 April). Info Corona. Diakses pada tanggal 18 April 2020, dari https://wonogirikab.go.id/index.php/info-corona/ 